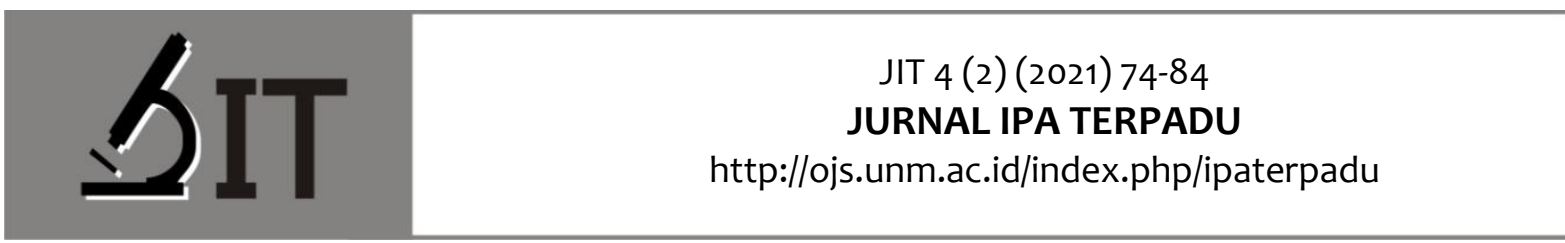

p-ISSN : 2597-8977

e-ISSN : 2597-8985

Siti Miluningtias

Universitas Muhammadiyah Sidoarjo

Noly Shofiyah*) Universitas Muhammadiyah Sidoarjo

*) Correspondence Author: nolyshofiyah@umsida.ac.id

\section{PENERAPAN GAME EDUKASI TERINTEGRASI KEARIFAN LOKAL BERBASIS ANDROID TERHADAP HASIL BELAJAR SISWA DALAM PEMBELAJARAN DARING}

Abstrak: Penelitian ini bertujuan untuk mendeskripsikan hasil belajar kognitif siswa setelah belajar menggunakan game edukasi terintegrasi kearifan lokal berbasis android serta mengetahui pengaruh penerapan game edukasi terintegrasi kearifan lokal berbasis android terhadap hasil belajar kognitif siswa. Penelitian ini menggunakan metode kuantitatif dengan rancangan one group pretest-posttest design dengan satu kelas eksperimen dan dua kelas replikasi. Populasi yang digunakan adalah siswa kelas VIII tahun ajaran 2020/2021. Pengambilan sampel dengan teknik sampling purposive. Teknik pengumpulan data penelitian ini menggunakan metode tes untuk mengetahui hasil belajar siswa. Analisis data menggunakan uji paired sample t-test. Hasil penelitian menunjukkan siswa kelas eksperimen yang lulus KKM pada materi gerak dan gaya sebesar $71.4 \%$ dengan kategori baik, siswa kelas replikasi 1 sebesar $41.4 \%$ dengan kategori cukup, dan siswa kelas replikasi 2 sebesar $78.5 \%$ dengan kategori sangat baik. Berdasarkan hasil analisis uji t menggunakan paired sample ttest diperoleh nilai signifikan pada kelas eksperimen sebesar 0.000 , kelas replika 1 sebesar 0.000 dan kelas replika 2 sebesar 0.000 dimana semua nilai signifikan < taraf signifikan (5\%). Sehingga disimpulkan bahwa game edukasi terintegrasi kearifan lokal berbasis android berpengaruh pada hasil belajar siswa kelas VIII SMP Negeri 3 Sidoarjo.

Kata Kunci: Game Edukasi, Kearifan Lokal, Hasil Belajar Kognitif.

Abstract: This study aimed to describe the cognitive learning outcomes of students after learning using android-based local wisdom integrated educational games and to determine the effect of the application of integrated educational games based on android based local wisdom on student cognitive learning outcomes. This research use quantitative methods with one group pretest-posttest design with one experimental class and two replication classes. The population used was grade VIII students for the $2020 / 2021$ school year. Sampling with purposive sampling technique. Data collection technique of this research use the test method to determine student learning outcomes. Data analysis used paired sample t-test. The results showed the experimental class students who passed passing grade were $71.4 \%$ in good category, $41.4 \%$ of the replication 1 class students were in enough category, and the replication 2 class students were $78.5 \%$ in very good category. This study found the significant value in the experimental class was 0.000 , the replica class 1 was 0.000 and the replica 2 class was 0.000 where all significant values <significant level (5\%). Therefore, it can be concluded that integrated educational game of local wisdom based on android affects the learning outcomes of grade VIII students of SMP Negeri 3 Sidoarjo.

Keyword: Education Game, Local Wisdom, Cognitive Learning Outcomes 


\section{PENDAHULUAN}

Pendidikan adalah salah satu bagian penting dalam kehidupan manusia dalam pengembangan kepribadian serta kemampuan (Ningrum, 2016). Pendidikan di Indonesia dari waktu ke waktu senantiasa ditingkatkan kualitasnya, salah satunya dengan cara mengembangkan dan memperbarui kurikulum. Kurikulum merupakan komponen penting dalam sistem pendidikan yang menjadi acuan di setiap satuan pendidikan. Kurikulum IPA SMP menekankan pada pembelajaran dengan memberikan pengalaman secara langsung kepada siswa dalam mempelajari peristiwa yang terjadi di lingkungan sekitar, kehidupan sehari-hari dan masyarakat modern yang sarat dengan teknologi (Anggareni et al., 2013). Pernyataan tersebut selaras dengan Permendiknas No 22. Tahun 2006 yang menyatakan bahwa pembelajaran IPA di SMP mengarahkan peserta didik untuk memperoleh pengalaman langsung dalam kegiatan belajarnya, sehingga dapat menambah kekuatan untuk menerima, menyimpan, dan menerapkan konsep yang telah disampaikan. Pembelajaran IPA di SMP perlu dilakukan dengan menggunakan pendekatan multistrategi, multimedia, dan memperdayakan kondisi alam, sosial, dan budaya.

Pembelajaran IPA dapat dikembangkan dengan bertumpu pada keunikan dan keunggulan dari suatu daerah, termasuk budaya dan kearifan lokal di masyarakat sehingga mampu menghantarkan siswa untuk mencintai daerah dan bangsanya (Bakti et al., 2018); (Damayanti et al., 2013). Selain itu pemerintah juga telah mendukung upaya pelestarian budaya dengan memasukkan program pembelajaran berbasis budaya lokal yang ditetapkan dalam Peraturan Pemerintah Nomor 19 Tahun 2005 tentang Standar Nasional Pendidikan Pasal 14 ayat (1), disebutkan bahwa Kurikulum untuk SMP/MTs/SMPLB atau bentuk lain yang sederajat dapat memasukan pendidikan berbasis keunggulan lokal.

Menurut Joseph (Nisa et al., 2015) pembelajaran berbasis kearifan lokal sebagai bagian yang penting dalam pendidikan. Pembelajaran berbasis kearifan lokal membuat siswa mampu menghubungkan fenomena atau budaya yang terjadi pada masyarakat setempat dengan kajian secara ilmiah sehingga pembelajaran dapat diterima dengan lebih bermakna yang nantinya berdampak positif pada hasil belajar peserta didik (Rahmi, 2016). Hal tersebut ditunjang oleh pernyataan yang menyatakan bahwa prestasi belajar siswa dapat ditingkatkan dengan perpaduan antara sains asli dengan pembelajaran sains di lingkungan sekolah (Sudarmin, 2014).

Tahun 2020 dunia sedang dilanda pandemi Covid-19 (Coronavirus Disease 2019). Pandemi Covid-19 membawa dampak besar bagi beberapa sektor di Indonesia mulai dari kesehatan, ekonomi, dan tentunya pendidikan. Menteri pendidikan dan kebudayaan RI (Mendikbud) mengeluarkan surat edaran nomor 36962/MPK.A/HK/2020, yaitu mewajibkan untuk memberlakukan pembelajaran secara online (Daring), dan telah mengeluarkan beberapa kebijakan untuk mengatur kegiatan pembelajan selama masa pandemi ini yang dipaparkan dengan jelas.

Kebijakan belajar di rumah tentu membawa pengaruh pada hasil belajar siswa terutama pada hasil belajar kognitif siswa (Dewi, 2020). Banyak faktor yang mempengaruhi hal tersebut seperti keterbatasan akses internet, keterbatasan pemahaman siswa selama belajar online, keterbatasan komunikasi antara siswa dan guru, juga menurunnya motivasi belajar karena merasa belajar sendiri cukup sulit sebab tidak adanya interaksi secara langsung antar siswa dan guru (Sadikin \& Hamidah, 2020). Hal tersebut juga terjadi pada siswa SMPN 3 Sidoarjo. Berdasarkan dari hasil angket yang diberikan kepadaa siswa, mereka menyatakan bahwa siswa dapat belajar dengan lancar dengan bantuan orang tua di rumah, namun sebagian lagi mengalami kesulitan dalam memahami materi pembelajaran sehingga hasil belajarnyapun kurang baik. Hal ini ditunjukkan sebesar $53 \%$ siswa hasil belajar kognitifnya mencapai KKM atau Kriteria Ketuntasan Minimal yang telah ditentukan, dan yang tidak tuntas sebesar $47 \%$. Nilai KKM SMPN 3 Sidoarjo sebesar 75 . Sedangkan hasil wawancara dengan guru, menunjukkan bahwa materi dan penugasan diberikan melalui google classroom. Namun banyak siswa yang kurang memahami materi karena diskusi materi yang diajarkan terbatas melalui pesan yang ditulis di google classroom. 
Dalam peningkatan hasil belajar kognitif siswa di masa pandemi saat ini, diperlukan inovasi pembelajaran yang mampu membuat siswa semangat dalam belajar. Salah satunya adalah pembelajaran dengan menggunakan game edukasi. Beberapa penelitian relevan menyatakan bahwa penggunaan game edukasi pada pembelajaran mampu meningkatkan motivasi dan hasil belajar siswa (Adyani et al., 2017); (Arifah et al., 2019); (Andari, 2020). Game edukasi dinilai cocok untuk diimplementasikan dalam pembelajaran online karena mampu meningkatkan keaktifan siswa dalam belajar (Nurhayati, 2020). Beberapa peneliti juga mengembangkan game edukasi dengan mengintegrasikan budaya lokal. Game edukasi terintegrasi kearifan lokal berbasis android dapat dijadikan sebuah solusi di tengah pembelajaran saat Pandemi Covid-19 karena pada game edukasi tersebut terdapat menu materi dan game atau kuis yang bisa digunakan oleh siswa untuk belajar secara mandiri (Safitri et al., 2020). Selain itu materi yang disajikan pada game edukasi adalah materi yang telah dihubungkan dengan pengetahuan sains asli yang ada pada masyarakat melalui permainan tradisional dan beberapa aktivitas yang menunjukkan kearifan lokal pada masyarakat sehingga meskipun pembelajaran dilakukan secara mandiri, siswa tetap bisa mengenal budaya asli masyarakat (Ardiana \& Pandawana, 2017).

Berdasarkan uraian sebelumnya, maka penelitian ini bertujuan untuk mendeskripsikan hasil belajar kognitif siswa yang belajar menggunakan game edukasi terintegrasi kearifan lokal, serta mengidentifikasi ada tidaknya pengaruh penggunaan game edukasi berbasis android terintegrasi kearifan lokal terhadap hasil belajar siswa.

\section{METODE}

Penelitian ini menggunakan metode penelitian kuantitatif One Group Pretest-Posttest Design dengan satu kelas eksperimen dan dua kelas replikasi. Kelas replikasi dimaksudkan agar hasil penelitian memiliki kekuatan dan tidak didapat secara kebetulan (Adhim \& Jatmiko, 2015). Perlakuan yang diberikan pada setiap kelas sama yaitu pembelajaran dengan menggunakan game edukasi terintegrasi kearifan lokal berbasis android. Game edukasi terintegrasi kearifan lokal berbasis android merupakan media pembelajaran yang dikembangkan penulis. Sebelum game edukasi diimplementasikan pada pembelajaran, dilakukan validasi terlebih dahulu. Uji validitas pada penelitian ini menggunakan uji validitas konstruks (contruct validity) dimana pada pengujian ini menggunakan pendapat dari para ahli. Berdasarkan hasil validasi, game edukasi terintegrasi kearifan lokal dinyatakan layak untuk digunakan dengan sedikit revisi. Adapun instrument penelitian yang digunakan adalan Tes Hasil Belajar yang mengacu pada indikator pembelajaran berikut:
3.2.1 Menjelaskan konsep gerak lurus.
3.2.2 Menjelaskan perbedaan jarak dan perpindahan.
3.2.3 Menentukan kecepatan dan percepatan dari gerak suatu benda.
3.2.4 Menjelaskan konsep gaya.
3.2.5 Menjelaskan konsep hukum newton tentang gerak.
3.2.6 Menganalisis penerapan hukum newton pada gerah makhluk hidup dan benda.
3.2.7 Menentukan percepatan benda sesuai Hukum II Newton

Penelitian ini dilakukan pada siswa kelas VIII SMPN 3 Sidoarjo dengan jumlah populasi sebesar 280 siswa. Sedangkan sampel yang digunakan adalah kelas VIII H, VIII I, dan VIII J. Teknik sampling yang digunakan adalah teknik sampling nonprobability sampling menggunakan cara purposive sampling.

Sumber data dalam penelitian ini adalah nilai pretest dan posttest. Pretest dan posttest dilakukan dengan menggunakan google form. Analisis data pada penelitian ini yang pertama untuk mendeskripsikan hasil belajar siswa kognitif siswa yang mencapai KKM dan yang tidak mencapai KKM menggunakan rumus berikut: 
$P=\frac{\text { Jumlah siswa yang mendapat nilai di atas KKM }}{\text { Total Siswa }} \times 100 \%$

Analisis yang kedua untuk mengetahui apakah game edukasi terintegrasi kearifan lokal berbasis android berpengaruh terhadap hasil belajar kognitif siswa. Analisis ini menggunakan paired sample t-test. Sebelum melakukan uji paired sample t-test terlebih dahulu dilakukan uji normalitas dan uji homogenitas.

\section{HASIL DAN PEMBAHASAN}

1. Hasil

\section{a. Media Game Edukasi Terintegrasi Kearifan Lokal Berbasis Android}

Game edukasi yang digunakan dalam penelitian ini adalah game BerGaYa (Belajar Gerak dan Gaya). Game edukasi terintegrasi kearifan lokal berbasis android memuat materi pada K.D. 3.2 kelas VIII yaitu Menganalisis gerak lurus, pengaruh gaya terhadap gerak berdasarkan Hukum Newton, dan penerapannya pada gerak benda dan gerak makhluk hidup. Kearifan lokal yang dimaksud adalah permainan tradisional yang berhubungan dengan materi gerak dan gaya diantaranya konsep gerak lurus dengan permainan tabak/engklek, balap karung, balap kelompen, konsep gaya dengan permainan ketapel, pembuatan gerabah dengan tanah liat, tarik tambang. Berikut tampilan dari game BerGaYa:
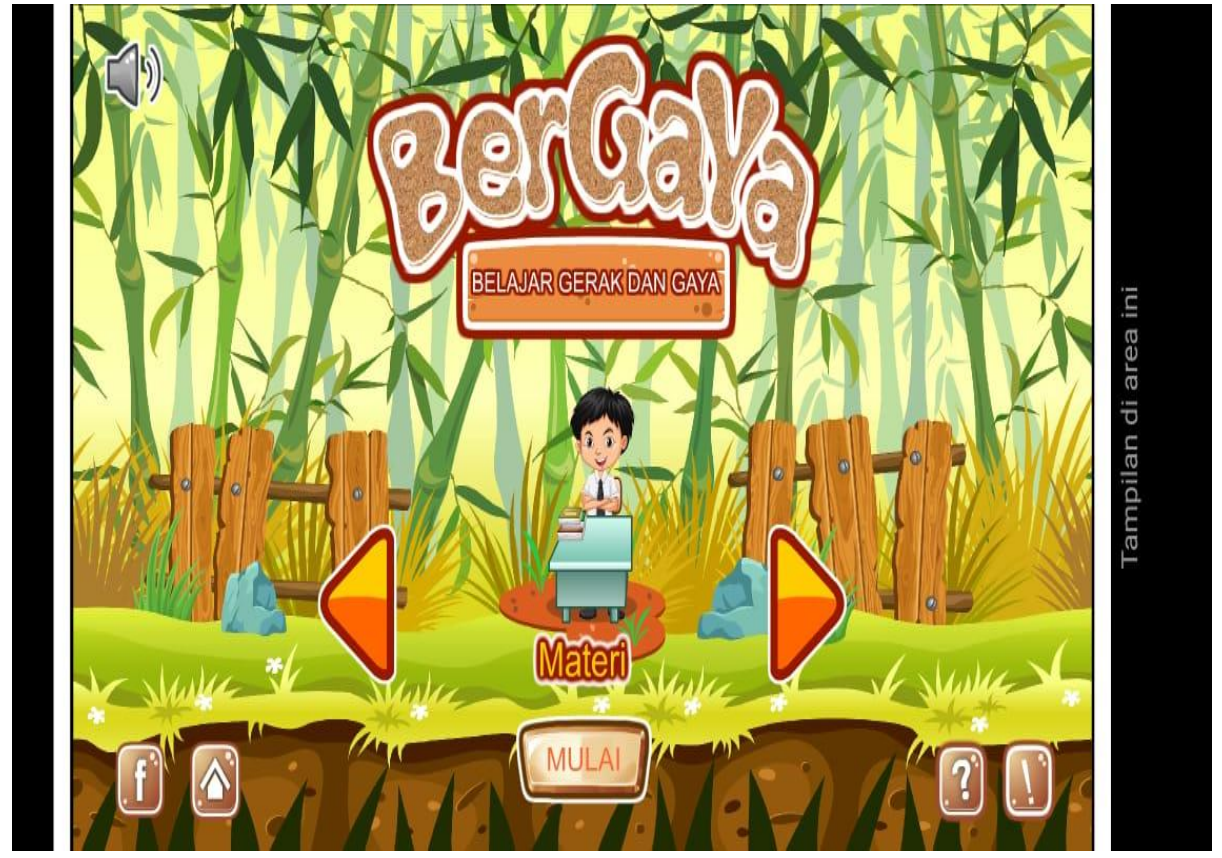

Gambar 1. Tampilan Menu Materi

Gambar 1 merupakan tampilan menu materi. Pada menu materi terdapat 3 menu materi yang bisa dipilih yaitu gerak, gaya dan hukum newton. Tampilan menu pada materi dapat dilihat pada Gambar 2. 

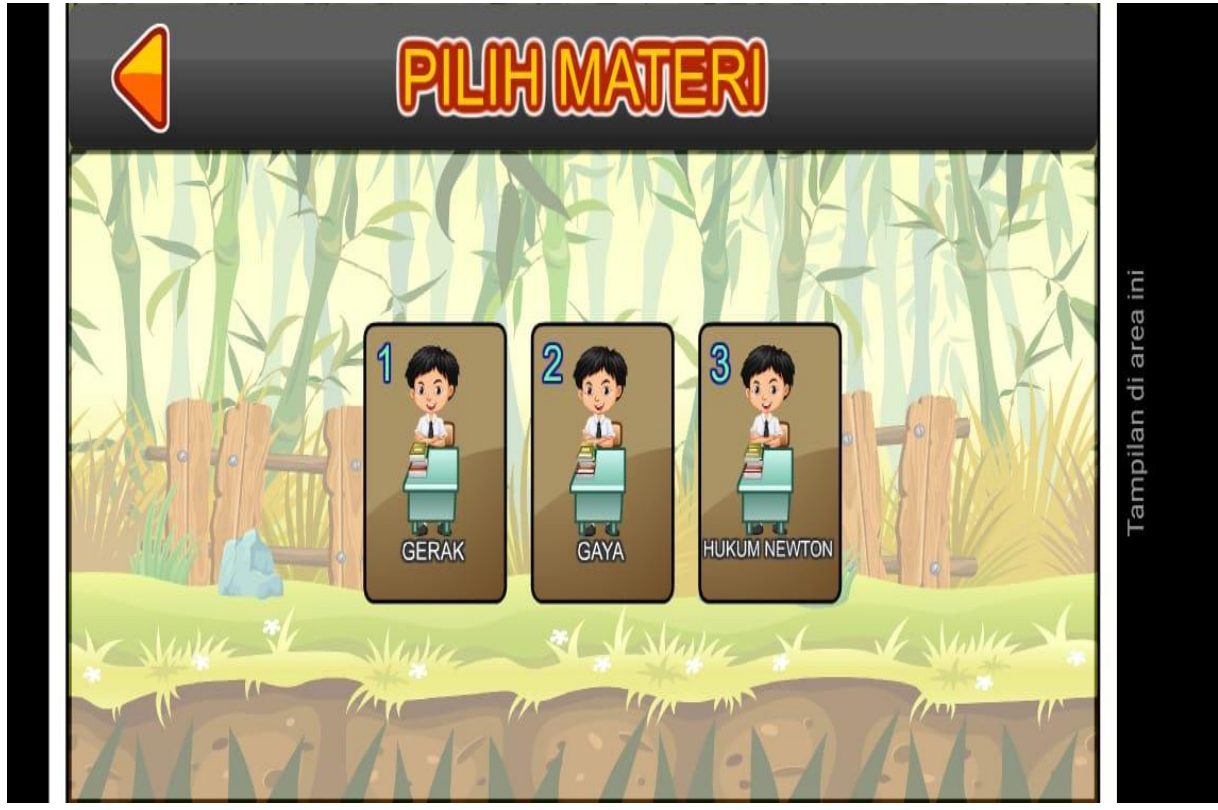

Gambar 2. Tampilan Menu-menu Materi

Gambar 2 merupakan tampilan menu-menu pada materi. Menu tersebut dapat dipilih sesuai dengan apa yang akan dipelajari. Di dalamnya terdapat materi yang telah dihubungkan dengan pengetahuan sains asli masyarakat melalui permainan tradisional. Selain menu materi terdapat menu permainan yang dapat dilihat pada Gambar 3.
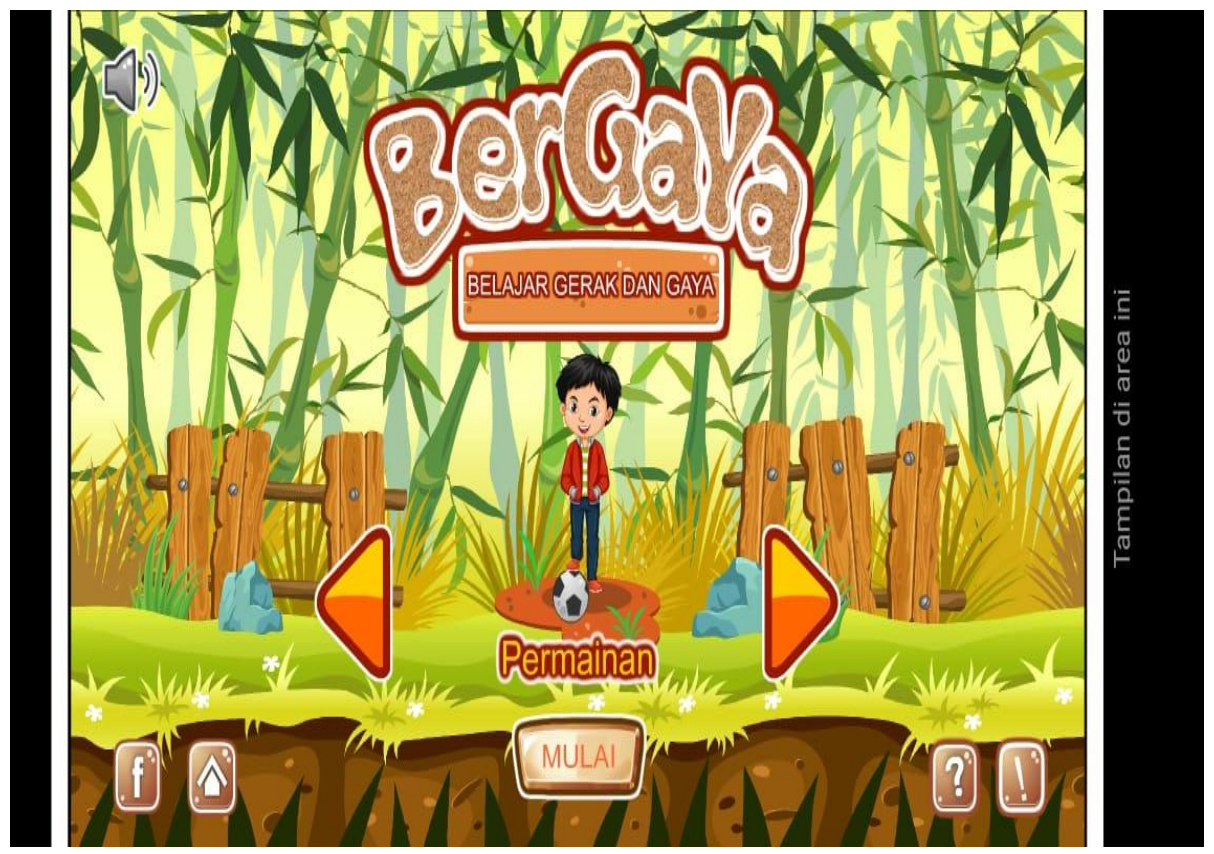

Gambar 3. Tampilan Menu Permainan

Gambar 3 merupakan tampilan dari menu permainan. Pada menu permainan ini terdapat latihan soal yang terbagi menjadi 4 tingkatan. Ketika siswa masuk dalam menu permainan, maka siswa harus menyelesaikan permainan dan tidak bisa keluar apabila belum bisa menyelesaikan permainan. 


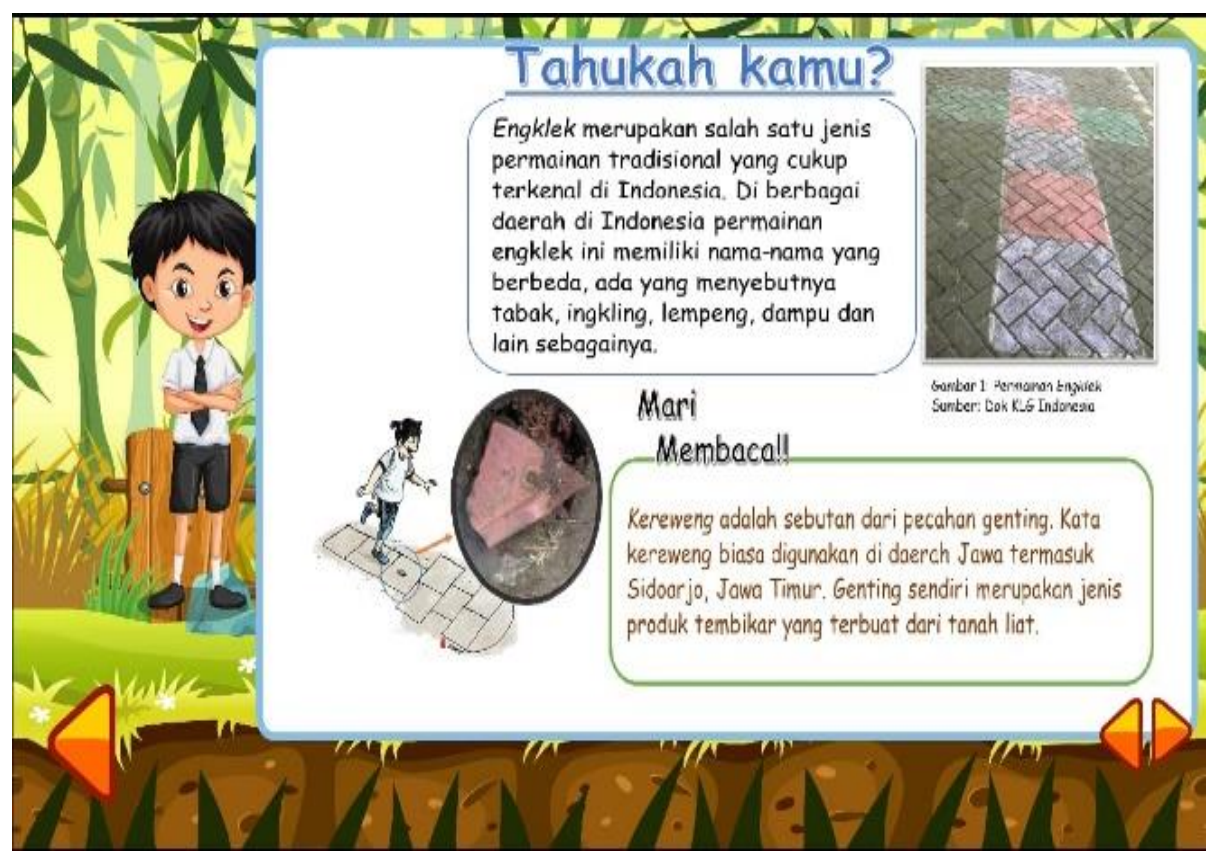

Gambar 4. Tampilan Integrasi Permainan Tradisional dalam Game

Selain menu-menu tersebut dalam media game edukasi juga terdapat penjelasan tentang permainan-permainan tradisional seperti permainan engklek, egrang, dan gangsing yang diintegrasikan dengan materi gerak dan gaya. Tampilan permainan tradisional dalam media dapat dilihat pada gambar 4. Melalui permainan engklek yang disajikan dalam game edukasi, siswa diminta untuk menentukan besar jarak dan perpindahan siswa yang melakukan permainan engklek. Konteks permainan tradisional disajikan untuk memudahkan siswa memahami konsep sesuai aplikasinya dimana dalam pembelajaran konteks yang disajikan harus relevan untuk siswa (perempuan dan laki-laki) (Jong, 2008).

\section{b. Ketercapaian Hasil Belajar Kognitif Siswa}

Berdasarkan hasil uji tes kognitif siswa pada materi gerak dan gaya diperoleh hasil ketercapaian indikator yang dapat dilihat pada gambar 5. Berdasarkan Gambar 5 dapat dilihat bahwa ketercapaian indikator materi gerak dan gaya pada kelas eksperimen, kelas replikasi 1 dan kelas replikasi 2 seluruhnya di atas 50\%. 


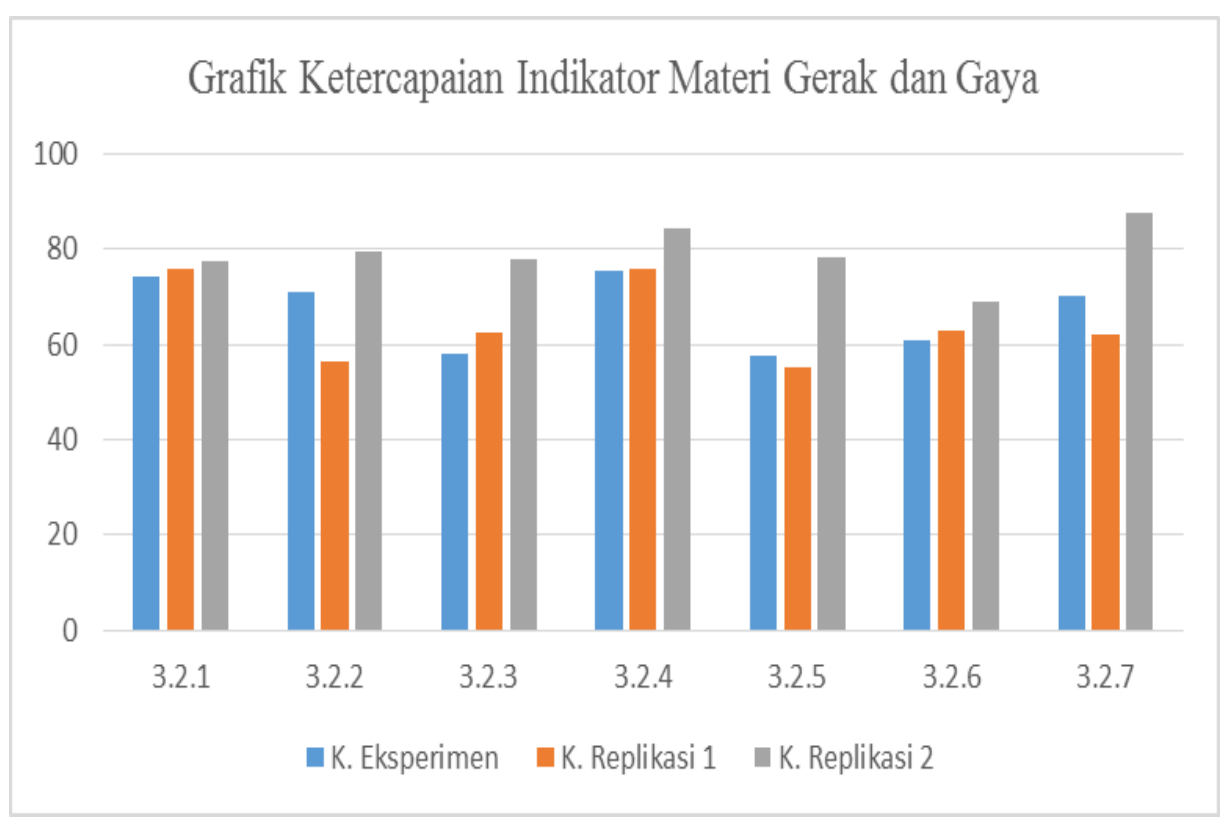

Gambar 5. Grafik Ketercapaian Indikator Materi Gerak dan Gaya

Grafik 5 menunjukkan dari ketiga kelas dapat dilihat bahwa kelas replikasi 2 ketercapaian indikatornya lebih tinggi bila dibandingkan dengan kelas eksperimen dan kelas replikasi 1. Ketercapaian indikator terbaik ada pada indikator 3.2.1 dan 3.2.4. Berikut Tabel 1 yang berisi data presentase KKM dari peserta didik dari ketiga kelas.

Tabel 1. Presentase KKM

\begin{tabular}{|c|c|c|}
\hline \multirow{2}{*}{ Kelas } & \multicolumn{2}{|c|}{ Persentase } \\
\hline & Lulus KKM & Tidak Lulus KKM \\
\hline Eksperimen & $71.4 \%$ & $28.6 \%$ \\
\hline Replikasi 1 & $41.4 \%$ & $58.6 \%$ \\
\hline Replikasi 2 & $78.5 \%$ & $21.5 \%$ \\
\hline
\end{tabular}

Berdasarkan Tabel 1 dapat dilihat bahwa kelas eksperimen untuk siswa yang lulus KKM pada materi gerak dan gaya sebesar $71.4 \%$ dengan kategori baik, kelas replikasi 1 sebesar $41.4 \%$ dengan kategori cukup, dan kelas replikasi 2 sebesar $78.5 \%$ dengan kategori sangat baik. Dari ketiga kelas hanya kelas replika 1 yang jumlah siswa lulus KKM lebih sedikit dibandingkan dengan yang tidak lulus KKM. Hal ini terjadi karena kemampuan awal kognitif siswa di kelas replikasi 1 memang tergolong lebih rendah dibandingkan dengan kemampuan kognitif awal siswa pada kelas eksperimen dan replikasi 2. Namun secara keseluruhan dapat disimpulkan bahwa pembelajaran materi gerak dan gaya menggunakan game edukasi terintegrasi kearifan lokal berbasis android membawa pengaruh cukup signifikan dilihat dari presentase siswa yang lulus KKM.

\section{c. Penerapan Game Edukasi Terintegrasi Kearifan Lokal Berbasis Android Terhadap Hasil Belajar Kognitif Siswa}

Sebelum melakukan uji t, peneliti terlebih dahulu melakukan uji prasyarat yang terdiri dari uji normalitas dan uji homogenitas. Uji normalitas dimaksudkan untuk mengetahui data yang disajikan berdistribusi normal atau tidak, sedangkan uji homogenitas untuk mengetahui data yang disajikan 
bersifat homogen. Kedua uji tersebut merupakan syarat dari uji parametrik. Pengujian diperoleh hasil data yang disajikan berdistribusi normal dan bersifat homogen. Hal ini dibuktikan nilai signifikasi pada uji normalitas Kolmogrov-Sminov Kelas Eksperimen sebesar 0.200, Kelas Replikasi 1 sebesar 0.001, dan Kelas Replikasi 2 sebesar 0.164. Sedangkan uji homogenitas sebesar 0.333. Sehingga data yang disajikan memenuhi syarat untuk pengujian hipotesis berikutnya.

Setelah melakukan uji prasyarat yaitu uji normalitas dan homogenitas, selanjutnya peneliti menguji hipotesis dengan menggunakan uji t menggunakan aplikasi SPSS 26.00. Adapun hipotesis penelitian ini yaitu:

- $H_{0}: \mu_{1}=\mu_{2}$, artinya tidak ada perbedaan antara hasil pretest dengan posttest.

- $H_{1}: \mu_{1} \neq \mu_{2}$, artinya ada perbedaan anatara hasil pretest dengan posttest.

Pengujian hipotesis dilakukan pada masing-masing kelas yaitu kelas eksperimen, kelas replikasi 1 dan kelas replikasi 2. Penelitian dinyatakan berhasil apabila menunjukkan peningkatan hasil belajar pada kelas eksperimen dan didukung peningkatan pada kelas replikasi.

Hasil dari perhitungan paired sample t-test nilai signifikansi kelas eksperimen sebesar 0.000 atau nilai signifikansi < taraf signifikan (5\%), maka $\mathrm{H}_{0}$ ditolak dan $\mathrm{H}_{1}$ diterima. Sehingga dapat dinyatakan pada kelas eksperimen terdapat perbedaan nilai antara pre-test dan post-test dengan diberikan perlakuan dengan pembelajaran menggunakan game edukasi terintegrasi kearifan lokal berbasis android.

Hasil dari kelas eksperimen didukung dengan hasil yang diperoleh dari kelas replikasi 1 dan kelas replikasi 2. Hasil perhitungan paired sample t-test kelas replikasi 1 menunjukkan nilai signifikasnsi kelas replikasi 1 sebesar 0.000 atau nilai signifikansi < taraf signifikan (5\%), sehingga pada kelas replikasi 1 tolak $\mathrm{H}_{0}$ dan terima $\mathrm{H}_{1}$. Hasil perhitungan paired sample t-test kelas replikasi 2 menunjukkan nilai signifikansi kelas replikasi 2 sebesar 0.000 atau nilai signifikansi $<$ taraf signifikan (5\%), sehingga pada kelas replikasi 2 tolak $\mathrm{H}_{0}$ dan terima $\mathrm{H}_{1}$.

\section{Pembahasan}

Penelitian ini menggunakan game edukasi terintegrasi kearifan lokal berbasis android atau game edukasi terintegrasi etnosains berbasis android pada materi gerak dan gaya kelas VIII. Penelitian ini dilakukan saat pandemi Covid-19, dimana banyak terjadi kontroversi terutama pada bidang pendidikan karena seluruh siswa di Indonesia melakukan pembelajaran secara daring di rumah. Adanya game edukasi terintegrasi kearifan lokal berbasis android ini bertujuan untuk membantu satu dari permasalahan siswa ketika pembelajaran daring di rumah yaitu kekurangaktifan mengikuti pembelajaran dan keterbatasan waktu orang tua dalam mendampingi anaknya saat pembelajaran daring (Asmuni, 2020).

Untuk mengetahui pengaruh dari game edukasi terintegrasi kearifan lokal berbasis android atau game edukasi terintegrasi kearifan lokal berbasis android terhadap hasil belajar siswa selama pandemi Covid-19, peneliti melakukan uji coba pada kelas VIII SMP Negeri 3 Sidoarjo. Penelitian ini mengambil dua data yaitu pretest atau sebelum perlakuan dan posttest sesudah perlakuan. Perlakuan yang dimaksudkan adalah memberikan pembelajaran dengan menggunakan game edukasi terintegrasi kearifan lokal berbasis android.

Pembelajaran yang dilakukan pada penelitian ini juga dibantu dengan platform google meet dan google classroom untuk membantu pemantauan belajar siswa. Untuk pretest dan posttest sendiri diberikan dengan menggunakan google form.

Berdasarkan hasil uji coba pembelajaran menggunakan game edukasi terintegrasi kearifan lokal berbasis android diperoleh hasil ketercapain indikator terbaik pada indikator 3.2.1 mengenai konsep gerak lurus dan indikator 3.2.4 mengenai konsep gaya. Hal ini menunjukkan pada bagian materi yang ada di game edukasi terintegrasi kearifan lokal berbasis android siswa lebih mudah memahami materi konsep gerak lurus dan konsep gaya dimana pada materi tersebut dihubungkan dengan kearifan lokal melalui permainan tradisional. Ketercapaian indikator terendah pada kelas 
eksperimen yaitu pada indikator 3.2.3 yaitu menentukan kecepatan dan percepatan dari gerak lurus suatu benda. Indikator 3.2.3 ini soal mengarah pada perhitungan dengan menggunakan persamaan kecepatan dan percepatan yang dihubungkan dengan kearifan lokal. Pada game edukasi terintegrasi kearifan lokal berbasis android ini sendiri memang materi untuk penerapan persamaan kecepatan dan percepatan lebih sedikit sehingga dimungkinkan siswa belum cukup memahami apabila dipelajari hanya satu kali. Pada kelas replikasi 1 ketercapaian indikator terendah yaitu indikator 3.2.5 tentang konsep hukum newton tentang gerak. Sedangkan pada kelas replikasi 2 ketercapian indikator terendah yaitu indikator 3.2.6 mengenai analisis penerapan hukum newton pada gerak. Pada game edukasi terintegrasi kearifan lokal berbasis android sendiri untuk materi hukum newton dijelaskan secara singkat dengan dihubungkan kearifan lokal, namun belum ada bagian contoh soal yang lebih mendalam. Hal ini sesuai dengan aspek yang harus dimiliki oleh media pembelajaran yaitu aspek desain (design) pembelajaran yang meliputi relevansi tujuan pembelajaran dengan KI dan KD, kesesuaian antara materi dengan tujuan pembelajaran, kejelasan dari uraian materi, kedalaman dari materi, kemudahan untuk dipahami dan sistematika materi (Pamungkas, 2016).

Selain pada ketercapaian indikator, peneliti juga melakukan analisis terkait ketercapaian siswa pada KKM yang telah ditentukan oleh sekolah. SMP Negeri 3 Sidoarjo menetapkan untuk mata pelajaran IPA nilai KKMnya sebesar 75. Setelah melakukan pembelajaran menggunakan game edukasi terintegrasi kearifan lokal berbasis android diperoleh hasil pada kelas eksperimen siswa yang lulus KKM sebesar $71.4 \%$ dan yang tidak lulus KKM sebesar $28.6 \%$. Pada kelas replikasi 1 siswa yang lulus KKM sebesar 41.4\% dan yang tidak lulus sebesar 58.6\%. Sedangkan pada kelas replikasi 2 siswa yang lulus KKM sebesar $78.5 \%$ dan yang tidak lulus sebesar $21.5 \%$.

Untuk mengetahui apakah pembelajaran menggunakan game edukasi terintegrasi kearifan lokal berbasis android berpengaruh atau tidak terhadap hasil belajar siswa SMP Negeri 3 Sidoarjo, peneliti melakukan uji t-test. Sebelum melakukan uji analisis t-test, peneliti melakukan uji normalitas dan uji homogenitas. Uji normalitas dimaksudkan untuk mengetahui data yang diperoleh merupakan data berdistribusi normal, sedangkan untuk uji homogenitas untuk mengetahui data yang diperoleh bersifat homogen. Hasil uji normalitas dapat dilihat pada Tabel 4.4 dan uji homogenitas pada Tabel 4.5. Dari ketiga kelas yaitu kelas eksperimen, kelas replika 1 dan kelas replika 2 telah memenuhi syarat untuk pengujian selanjutnya karena data dari ketiga kelas berdistribusi normal dan bersifat homogen.

Setelah melakukan uji normalitas dan uji homogenitas selanjutnya dilakukan uji t. Uji t yang digunakan adalah paired sample t-test. Paired sample t-test dilakukan menggunakan SPSS 26.0. Berdasarkan tabel 4.4 dapat dilihat secara perhitungan menggunakan paired sample t-test SPSS 26.0 diperoleh nilai signifikasi lebih kecil dari taraf signifikan (5\%) yang artinya terdapat perbedaan antara nilai pretest sebelum perlakuan dengan nilai posttest atau sesudah perlakuan. Dengan demikian pembelajaran dengan game edukasi terintegrasi kearifan lokal berbasis android yang terintegrasi etnosains dan berbasis android berpengaruh terhadap peningkatan hasil belajar kognitif siswa kelas VIII SMP Negeri 3 Sidoarjo. Hal ini sesuai dengan teori yang menyatakan education game (game edukasi) merupakan alat permainan edukatif (APE) sebagai sarana yang dapat merangsang aktivitas siswa agar mempelajari suatu materi pembelajaran serta dapat meningkatkan pemahaman pada materi tersebut (Susanto et al., 2013). Pembelajaran berbantuan media animasi interaktif berbasis game edukasi juga dinilai mampu meningkatkan motivasi belajar dan hasil belajar siswa (Adyani et al., 2017). Media pembelajaran berbasis game edukasi juga mampu meningkatkan pemahaman konsep siswa (Rachman et al., 2019). Selain itu, game edukasi yang diintegrasikan dengan budaya lokal juga mampu memotivasi dan memfasilitasi siswa untuk belajar mandiri dalam masa pandemic covid-19 (Suddin \& Deda, 2020).

Game edukasi terintegrasi kearifan lokal berbasis android yang digunakan pada penelitian ini masih memiliki kekurangan materi yang kurang detail, contoh soal yang masih kurang, dan belum adanya bagian pembahasan setelah kuis. Diharapkan peneliti selanjutnya dapat memenuhi 
beberapa cakupan materi yang kurang, menambahkan contoh soal yang lebih banyak dan memberikan menu pembahasan setelah kuis agar siswa lebih paham ketika belajar.

\section{KESIMPULAN}

Berdasarkan hasil penelitian penerapan game edukasi terintegrasi kearifan lokal berbasis android terhadap hasil belajar siswa SMP Negeri 3 Sidoarjo dapat disimpulkan hasil belajar kognitif siswa dari kelas eksperimen yang lulus KKM (Kriteria Ketuntasan Minimal) pada materi gerak dan gaya sebesar 71.4\% dengan kategori baik, hasil belajar kognitif siswa dari kelas replikasi 1 yang lulus KKM sebesar 41.4\% dengan kategori cukup, dan hasil belajar kognitif siswa dari kelas replikasi 2 yang lulus KKM sebesar 78.5\% dengan kategori sangat baik. Untuk mengetahui penerapan dari game edukasi terintegrasi kearifan lokal berbasis android terhadap hasil belajar kognitif siswa dilakukan uji t menggunakan paired sample t-test. Berdasarkan hasil analisis uji t menggunakan paired sample t-test diperoleh nilai signifikan pada kelas eksperimen sebesar 0.000 , kelas replikasi 1 sebesar 0.000 dan kelas replikasi 2 sebesar 0.000 dimana semua nilai signifikan < taraf signifikan (5\%). Sehingga disimpulkan bahwa game edukasi terintegrasi kearifan lokal berbasis android berpengaruh pada hasil belajar siswa kelas VIII SMP Negeri 3 Sidoarjo.

\section{DAFTAR PUSTAKA}

Adhim, A. Y., \& Jatmiko, B. (2015). Penerapan Model Pembelajaran Guided Discovery Dengan Kegiatan Laboratorium Untuk Meningkatkan Hasil Belajar Siswa Kelas X Sma Pada Materi Suhu Dan Kalor. Jurnal Inovasi Pendidikan Fisika (JIPF), 4(3), 77-82.

Adyani, L., Agustini, R., \& Raharjo, R. (2017). Pengembangan Perangkat Pembelajaran Berbantuan Media Animasi Interaktif Berbasis Game Edukasi Untuk Meningkatkan Motivasi Dan Hasil Belajar Siswa. JPPS (Jurnal Penelitian Pendidikan Sains), 4(2), 648. https://doi.org/10.26740/jpps.v4n2.p648-657

Andari, R. (2020). Pemanfaatan Media Pembelajaran Berbasis Game Edukasi Kahoot! Pada Pembelajaran Fisika. ORBITA: Jurnal Kajian, Inovasi Dan Aplikasi Pendidikan Fisika, 6(1), 135. https://doi.org/10.31764/orbita.v6i1.2069

Anggareni, N. W., Ristiati, N. P., \& Widiyanti, N. L. P. M. (2013). Implementasi Strategi Pembelajaran Inkuiri Terhadap Kemampuan Berpikir Kritis Dan Pemahaman Konsep IPA Siswa SMP. EJournal Program Pascasarjana Universitas Pendidikan Ganesha, 3, 1-11.

Ardiana, D. P. Y., \& Pandawana, I. D. G. A. (2017). Aplikasi Game Cerita Rakyat Bali Sebagai Sarana Pendidikan Karakter Anak Berbasis Mobile. Lontar Komputer : Jurnal Ilmiah Teknologi Informasi, 8(3), 208. https://doi.org/10.24843/lkjiti.2017.v08.io3.po7

Arifah, R. E. N., Sukirman, S., \& Sujalwo, S. (2019). Pengembangan Game Edukasi Bilomatika untuk Meningkatkan Hasil Belajar Siswa pada Mata Pelajaran Matematika Kelas 1 SD. Jurnal Teknologi Informasi Dan Ilmu Komputer, 6(6), 617. https://doi.org/10.25126/jtiik.2019661310

Asmuni, A. (2020). Problematika Pembelajaran Daring di Masa Pandemi Covid-19 dan Solusi Pemecahannya. Jurnal Paedagogy, 7(4), 281. https://doi.org/10.33394/jp.v7i4.2941

Bakti, I., Sumartias, S., Damayanti, T., \& Nugraha, A. R. (2018). Pengembangan Model Komunikasi Pariwisata Berbasis Kearifan Lokal di Kawasan Geopark Pangandaran. Jurnal Kajian Komunikasi, 6(2), 217. https://doi.org/10.24198/jkk.v6i2.18459

Damayanti, C., Dewi, N. R., \& Akhlis, I. (2013). Pengembangan CD Pembelajaran Berbasis Kearifan Lokal Tema Getaran Dan Gelombang Untuk Siswa Smp Kelas VIII. USEJ - Unnes Science Education Journal, 2(2), 274-281. https://doi.org/10.15294/usej.v2i2.2036

Dewi, W. A. F. (2020). Dampak COVID-19 terhadap Implementasi Pembelajaran Daring di Sekolah Dasar. Edukatif : Jurnal Ilmu Pendidikan, 2(1), 55-61. https://doi.org/10.31004/edukatif.v2i1.89

Jong, O. De. (2008). Context-based Chemical Education: How to improve it? Chemical Education 
International, July, 1-7. http://old.iupac.org/publications/cei/vol8/0801xDeJong.pdf

Ningrum, E. (2016). Pengembangan Sumber Daya Manusia Bidang Pendidikan. Jurnal Geografi Gea, 9(1). https://doi.org/10.17509/gea.vgi1.1681

Nisa, A., Sudarmin, \& Samini. (2015). Efektivitas Penggunaan Modul Terintegrasi Etnosains dalam Pembelajaran Berbasis Masalah untuk Meningkatkan Literasi Sains Siswa. Unnes Science Education Journal, 4(3), 1049-1056.

Nurhayati, E. (2020). Meningkatkan Keaktifan Siswa Dalam Pembelajaran Daring Melalui Media Game Edukasi Quiziz pada Masa Pencegahan Penyebaran Covid-19. Jurnal Paedagogy, 7(3), 145. https://doi.org/10.33394/jp.v7i3.2645

Pamungkas, A. J. (2016). Pengembangan Media Pembelajaran Game Edukasi IPA Terpadu Pada Tema Tekanan Terhadap Aktivitas \& Prestasi Belajar Siswa.

Rachman, A., Purwanto, M. Y., \& Nugroho, H. (2019). Development of Educational Games for The Introduction of Fruits and Vitamins. Journal of Educational Science and Technology (EST), 5(1), 76-81. https://doi.org/10.26858/est.v5i1.8495

Rahmi, S. A. (2016). Pembangunan Pariwisata Dalam Perspektif Kearifan Lokal. Reformasi, 6(1), 76 84.

Sadikin, A., \& Hamidah, A. (2020). Pembelajaran Daring di Tengah Wabah Covid-19. Biodik, 6(2), 109119. https://doi.org/10.22437/bio.v6i2.9759

Safitri, A. W., Pujiastuti, H., \& Sudiana, R. (2020). Pengembangan Game Edukasi dengan Konteks Kearifan Lokal Banten pada Materi Matriks. Journal of Medives : Journal of Mathematics Education IKIP Veteran Semarang, 4(2), 319. https://doi.org/10.31331/medivesveteran.v4i2.1171

Sudarmin, S. (2014). Pendidikan karakter, etnosains dan kearifan lokal. Unnes Semarang.

Suddin, S., \& Deda, Y. N. (2020). Education Game based on Timor Local Wisdom as an Android-Based Mathematics Learning Media. Al-Jabar : Jurnal Pendidikan Matematika, 11(2), 227-246. https://doi.org/10.24042/ajpm.v11i2.6958

Susanto, Dewi, N. R., \& Irsadi, A. (2013). PENGEMBANGAN MULTIMEDIA INTERAKTIF DENGAN EDUCATION GAME PADA PEMBELAJARAN IPA TERPADU TEMA CAHAYA UNTUK SISWA SMP/MTs. USEJ - Unnes Science Education Journal, 2(1), 230-238. https://doi.org/10.15294/usej.v2i1.1829

Received, 31 Januari 2021

Accepted, 29 Maret 2021

\section{Siti Miluningtias}

Mahasiswa Pendidikan IPA, Universitas Muhammadiyah Sidoarjo, sitimiluningtyas@gmail.com

\section{Noly Shofiyah (Co Author)}

Dosen Pendidikan IPA, Universitas Muhammadiyah Sidoarjo, nolyshofiyah@umsida.ac.id 